\title{
METODE QUANTUM LEARNING DAN KEMAMPUAN BERPIKIR KREATIF MATEMATIS SISWA SMP NEGERI 5 SEKAYU
}

\author{
Pipin Meida $^{1}$, Misdalina $^{2}$, Nora Surmilasari ${ }^{3}$ \\ Universitas PGRI Palembang ${ }^{1,2,3}$ \\ norasurmilasari@gmail.com ${ }^{3}$
}

\begin{abstract}
ABSTRAK
Penelitian ini bertujuan untuk mengetahui pengaruh metode Quantum Learning terhadap kemampuan berpikir kreatif dalam pembelajaran matematika di SMP Negeri 5 Sekayu. Metode penelitian yang digunakan adalah metode eksperimen dengan menggunakan posstest-only control design. Populasi dalam penelitian ini adalah siswa kelas VII SMP Negeri 5 Sekayu dan sampel yang digunakan adalah siswa kelas VII.2 sebagai kelas eksperimen dan kelas VII.1 sebagai kelas kontrol. Penelitian ini berlangsung mulai tanggal 18 September 2019 sampai 4 Oktober 2019. Teknik pengumpulan data menggunakan tes yang dilakukan pada akhir pembelajaran. Teknik analisis data menggunakan uji t. Berdasarkan analisis data nilai signifikan uji t yaitu 0,001 kurang dari angka kritis 0,025, sehingga dapat disimpulkan bahwa metode Quantum Learning berpengaruh positif terhadap kemampuan berpikir kreatif siswa kelas VII SMP Negeri 5 Sekayu.
\end{abstract}

Kata kunci : quantum learning, berpikir kreatif

\begin{abstract}
This study aims to determine the effect of the Quantum Learning method on the ability to think creatively in mathematics learning at Sekayu 5 Middle School. The research method used was an experimental method using a post-test-only control design. The population in this study were students of class VII of SMP Negeri 5 Sekayu and the sample used was students of class VII.2 as the experimental class and class VII.1 as the control class. This research conducted on 18 September 2019 to 4 October 2019. Data collection techniques used were tests conducted at the end of learning. Data analysis techniques used t-test. Based on the data analysis the significant value of the t-test is 0.001 less than the critical number of 0.025 , so it can be concluded that the Quantum Learning method has a positive effect on the creative thinking ability of Grade VII students of SMP Negeri 5 Sekayu.
\end{abstract}

Keywords : quantum learning, creative thinking 


\section{PENDAHULUAN}

Pembelajaran matematika adalah suatu proses belajar-mengajar yang dibangun oleh guru untuk mengembangkan kreativitas berpikir yang dapat meningkatkan kemampuan berpikir siswa, serta dapat meningkatkan kemampuan mengkontruksi pengetahuan baru sebagai upaya meningkatkan penguasaan yang baik terhadap materi matematika. Siswono (2006) menyatakan bahwa salah satu tujuan pembelajaran matematika adalah mengembangkan aktivitas kreatif yang melibatkan imajinasi, intuisi dan penemuan, dengan mengembangkan pemikiran divergen, orisinal, rasa ingin tahu, membuat prediksi dan dugaan serta mencoba-coba. Hal ini mengisyaratkan pentingnya mengembangkan kemampuan berpikir kreatif matematik melalui aktivitas-aktivitas kreatif dalam pembelajaran matematika.

Kemampuan berpikir kreatif sangat ditentukan oleh kreativitas. Orang yang memiliki kreativitas tinggi maka ia akan memiliki kemampuan untuk berpikir kreatif. Sehingga kreativitas merupakan cara untuk menuju kemampuan berpikir kreatif. Seperti yang dinyatakan oleh Mardianto (2012), kreativitas adalah produk dari cara berpikir yang baik dan benar. Sedangkan Munandar (1999) menyatakan bahwa kreativitas adalah kemampuan umum untuk menciptakan sesuatu yang baru, karena kemampuan untuk memberikan ide baru yang bisa diterapkan pada pemecahan masalah, atau sebagai kemampuan untuk mengetahui hubungan antara unsur yang sudah ada.

Orang yang kreatif sangat menyukai tantangan dan selalu yakin bahwa setiap permasalahan memiliki solusi. Orang yang kreatif juga sudah biasa terbuka terhadap ide baru dan berani mengambil resiko atas ide barunya tersebut walaupun tidak mendapat respon dari lingkungannya.

Berpikir kreatif merupakan suatu proses berpikir untuk mengungkapkan hubungan-hubungan baru, melihat sesuatu dari sudut pandang baru dan membentuk kombinasi baru dari dua konsep atau lebih yang sudah dikuasai sebelumnya (Suryadi dan Herman, 2008:23). Kemampuan seseorang untuk menghasilkan berpikir kreatif ini disebut sebagai kemampuan berpikir kreatif, dan secara umum ditandai dengan adanya kemampuan berpikir lancar (fluency), kemampuan berpikir luwes (flexibility), kemampuan berpikir orisinal (originality), dan kemampuan merinci (elaboration).

Pada kenyataannya kemampuan berpikir kreatif siswa kurang berkembang, khususnya siswa-siswi SMP Negeri 5 Sekayu. Berdasarkan analisis hasil belajar siswa dan wawancara dengan guru matematika SMP Negeri 5 Sekayu, menunjukkan bahwa kemampuan berpikir kreatif matematis siswa tergolong rendah. Berdasarkan hasil observasi yang dilakukan di SMP Negeri 5 Sekayu pun menunjukkan bahwa kemampuan berpikir kreatif siswa masih rendah. Oleh karena itu, harus ada strategi pembelajaran yang dapat memberdayakan semua potensi yang tersedia untuk mencapai tujuan pembelajaran secara keseluruhan.

Salah satu upaya peningkatan kemampuan berpikir kreatif adalah kemampuan guru dalam menyampaikan materi pelajaran. Guru sebagai motivator dan fasilitator dituntut untuk mampu mengembangkan atau menumbuhkan dan bisa menghubungkan hal-hal yang sudah diketahui menjadi pengertian yang lebih sempurna.

Salah satu metode yang dapat digunakan guru dalam pembelajaran yaitu metode quantum learning. Quantum learning ini digagas oleh DePorter. Metode ini merupakan kiat, petunjuk, strategi dan seluruh proses belajar yang dapat mempertajam pemahaman dan daya ingat, serta membuat belajar sebagai suatu 
proses yang menyenangkan dan bermanfaat. Pembelajaran quantum membiasakan siswa untuk melatih aktifitas kreatifnya sehingga siswa dapat menciptakan suatu produk yang kreatif yang dapat bermanfaat bagi diri dan lingkungannya. Siswa dirangsang untuk aktif mengamati, menyesuaikan antara teori dengan kenyataan, dan dapat mencoba melakukannya sendiri.

Quantum learning adalah seperangkat metode dan falsafah belajar yang terbukti efektif untuk semua tipe orang dan segala usia. Quantum learning pertama kali digunakan di Supercamp. Di Supercamp ini menggabungkan rasa percaya diri, keterampilan belajar, dan keterampilan berkomunikasi dalam lingkungan yang menyenangkan (DePorter dan Hernacki, 2007).

Pembelajaran quantum adalah membawa dunia siswa ke dalam dunia guru. Dan mengantarkan dunia guru ke dunia siswa. Guru hanya sebagai fasilitator. Sehingga guru harus memahami potensi siswa terlebih dahulu. Salah satu cara yang dapat digunakan dalam hal ini adalah mengaitkan apa yang akan diajarkan dengan peristiwa-peristiwa, pikiran, atau perasaan, tindakan yang diperoleh siswa dalam kehidupan baik di rumah, di sekolah, maupun di lingkungan masyarakat. Apabila seorang guru telah memahami dunia siswa, maka siswa telah merasa diperlakukan sebagaimana mestinya, sehingga pembelajaran akan menjadi harmonis (DePorter dan Hernacki, 2007).

Pembelajaran quantum yaitu meningkatkan partisipasi siswa melalui pengubahan keadaan, meningkatkan motivasi dan minat belajar, meningkatkan rasa kebersamaan, meningkatkan daya dengar, dan meningkatkan kehalusan perilaku (DePorter dan Hernacki, 2007).

Prinsip quantum learning adalah segalanya berbicara, segalanya bertujuan, pengalaman sebelum pemberian nama, akui setiap usaha, jika layak dipelajari maka layak pula dirayakan. Segalanya berbicara seperti halnya lingkungan kelas dan bahasa tubuh yang mengirimkan pesan untuk belajar. Segalanya bertujuan, segala sesuatu yang berhubungan dengan proses pembelajaran memiliki tujuan. Proses belajar yang paling baik terjadi ketika siswa telah mengalami informasi sebelum mereka memperoleh nama yang mereka pelajari. Ketika anak itu sudah mulai untuk belajar yang bagaimanapun untuk setiap usaha dan pekerjaan untuk belajar yang dilakukan selalu dianggap perlu dan akan berpengaruh terhadap hasil pekerjaan yang lebih baik. Apabila layak dipelajari, maka layak pula dirayakan, perayaan merupakan ungkapan kegembiraan atas keberhasilan yang diperoleh dan juga dengan perayaan dapat memberi umpan balik yang positif. Prinsip ini dapat digunakan dalam pembelajaran matematika (Astuti, 2017).

Jadi pembelajaran quantum learning itu menciptakan suasana belajar yang kondusif untuk membangun sugesti. Misalnya, memasang musik latar di dalam kelas, pelajar bisa duduk secara nyaman, membuka lebar-lebar partisipasi individu, serta menyediakan guru yang terlatih bukan saja ia menguasai benar mata pelajarannya, tapi juga seni memberi sugesti. Guru dapat melakukannya dengan cara mengaitkan yang diajarkan dengan sebuah peristiwa, pikiran, atau perasaan yang diperoleh dari kehidupan rumah, sosial, atletik, musik, seni, rekreasi atau akademis mereka.

Untuk mempermudah mengingat dan untuk keperluan operasional dalam quantum learning maka dalam prosesnya terdapat suatu konsep yang disebut konsep TANDUR. Konsep ini membentuk basis struktur yang melandasi model quantum learning (Sugiyanto, 2009:83). 
Konsep TANDUR merupakan akronim dari Tumbuhkan, Alami, Namai, Demonstrasikan, Ulangi dan Rayakan (Fatahuddin, 2011) : 1) Tumbuhkan : memikat siswa dengan menyertakan mereka dalam proses pembelajaran dan memuaskan proses belajar; 2) Alami : memberikan pengalaman belajar untuk menumbuhkan "kebutuhan untuk mengetahui"; 3) Namai : berikan apa yang mereka inginkan, tepat saat minat mereka memuncak; 4) Demonstrasikan : hal ini berarti memberikan kesempatan mereka untuk mengaitkan pengalaman dengan data baru; 5) Ulangi : rekatkan keseluruhan materi pembelajaran; 6) Rayakan : perayaan akan menandakan kesan rampung, menghormati usaha, ketekunan dan kesuksesan.

Dengan konsep TANDUR ini, maka diharapkan dalam proses pembelajaran quantum learning akan menumbuhkan minat siswa, menumbuhkan rasa ingin tahu siswa, memberikan kesempatan untuk bertanya, mengaitkan materi dengan kehidupan sehari-hari, dan mengembangkan kemampuan akademis dan keterampilan siswa.

Penelitian yang dilakukan Swandewi, Gita dan Suarsana (2019) mendukung keadaan tersebut. Berdasarkan hasil penelitiannya menunjukkan bahwa model pembelajaran quantum learning berpengaruh terhadap kemampuan berpikir kreatif siswa SMA dan dapat memotivasi siswa lebih kreatif dalam mengembangkan pengetahuan serta keterampilannya. Hasil penelitian Anisa, Medriati, dan Putri (2019) juga menunjukkan bahwa model pembelajaran quantum learning berpengaruh terhadap hasil belajar siswa.

Berdasarkan uraian di atas, dan sehubungan juga dengan permasalahan pembelajaran matematika di SMP Negeri 5 Sekayu, maka perlu dilakukan penelitian yang bertujuan untuk mengetahui pengaruh yang signifikan metode quantum learning terhadap kemampuan berpikir kreatif siswa dalam pembelajaran matematika di SMP Negeri 5 Sekayu. Pada penelitian ini diterapkan konsep TANDUR pada pembelajaran matematika di SMP Negeri 5 Sekayu.

\section{METODE}

Penelitian ini menggunakan jenis penelitian eksperimen dengan metode posstest-only control design yaitu suatu metode yang menggunakan dua kelompok yang masing-masing dipilih secara acak (random sampling) yang terdiri dari kelas eksperimen dan kelas kontrol. Kelas eksperimen diberi perlakuan dengan menggunakan metode quantum learning dan kelas kontrol yang diajarkan dengan metode konvensional.

Penelitian ini dilaksanakan di SMP Negeri 5 Sekayu yang beralamatkan di J1. Inpres LK. III Serasan Jaya Kecamatan Sekayu pada semester ganjil 2019/2020. Penelitian ini berlangsung mulai tanggal 18 September 2019 sampai 4 Oktober 2019. Kegiatan penelitian ini dilaksanakan sebanyak empat pertemuan dengan tiga tahap, yaitu tahap perencanaan, tahap pelaksanaan, dan pelaporan. Materi matematika yang diberikan pada saat penelitian yaitu materi himpunan.

Populasi penelitian ini adalah siswa kelas VII sebanyak empat kelas. Dilakukan pengundian secara acak untuk memilih kelas sebagai sampel, sehingga terpilih kelas VII.2 sebagai kelas eksperimen dengan jumlah 29 siswa, yang terdiri dari 15 siswa laki-laki dan 14 siswa perempuan, dan kelas VII.1 sebagai kelas kontrol dengan jumlah 28 siswa, yang terdiri dari 13 siswa laki-laki dan 15 siswa perempuan. 
Teknik pengumpulan data yang digunakan dalam penelitian ini adalah teknik pemberian tes yang dilakukan di akhir pembelajaran. Setiap soal dibuat dengan mengacu pada indikator kemampuan berpikir kreatif. Indikator kemampuan berpikir kreatif yang diacu yaitu indikator menurut Munandar (1999) : (1) Berpikir lancar (fluency) dengan ciri-ciri mencetuskan banyak gagasan, jawaban, penyelesaian masalah atau pertanyaan, memberikan banyak cara atau saran untuk melakukan berbagai hal, dan selalu memikirkan lebih dari satu jawaban; (2) Berpikir luwes (flexibility) dengan ciri-ciri menghasilkan, gagasan, jawaban, atau pertanyaan yang lebih bervariasi, dapat melihat masalah dari sudut pandang yang berbeda-beda, mencari banyak alternatif atau arah yang berbeda-beda, mampu mengubah cara pendekatan atau cara pemikiran; (3) Berpikir orisinal (originality) dengan ciri-ciri mampu mengungkapkan hal yang baru dan unik, memikirkan cara yang tidak lazim untuk mengungkapkan diri, dan mampu membuat kondisi yang tidak lazim di bagian-bagian atau unsur-unsur; dan (4) Merinci (elaboration) dengan ciri-ciri mampu memperkaya dan mengembangkan suatu gagasan atau produk, menambah atau memerinci secara detail dari suatu objek, dan gagasan atau situasi sehingga menjadi lebih menarik.

Postes dilakukan untuk mengetahui kemampuan berpikir kreatif matematis siswa. Tes dilaksanakan pada dua kelas yaitu kelas eksperimen dan kelas kontrol. Soal yang diberikan merupakan soal uraian. Hasil jawaban siswa diberi skor sesuai dengan pedoman penskoran tes kemampuan berpikir kreatif matematis. Dari total skor yang diperoleh siswa akan ditentukan nilai tes. Data hasil penelitian dianalisis dengan menggunakan uji normalitas, uji homogenitas, dan uji t.

\section{HASIL DAN PEMBAHASAN}

Setelah dilakukan pembelajaran dengan menggunakan metode quantum learning dan konvensional, diadakan tes tertulis kemampuan berpikir kreatif terhadap siswa. Berdasarkan analisis data diperoleh nilai rata-rata perindikator dan keseluruhan tes akhir yang tertera pada tabel 1 berikut :

Tabel 1. Berpikir kreatif kelas eksperimen dan kontrol

\begin{tabular}{cccccc}
\hline \multirow{2}{*}{ No } & \multirow{2}{*}{ Indikator } & \multicolumn{2}{c}{ Eksperimen } & \multicolumn{2}{c}{ Kontrol } \\
\cline { 3 - 6 } & & Jumlah skor & Mean & Jumlah skor & Mean \\
\hline 1 & Berpikir lancar & 96 & 3,31 & 82 & 2,83 \\
2 & Berpikir luwes & 191 & 6,59 & 162 & 5,59 \\
3 & Berpikir orisinal & 209 & 7,21 & 158 & 5,45 \\
4 & Berpikir merinci & 169 & 5,83 & 156 & 5,38 \\
\hline & Keseluruhan & 665 & 22,93 & 558 & 19,24 \\
\hline
\end{tabular}

Pada tabel di atas dapat dilihat bahwa berdasarkan indikator kemampuan berpikir kreatif siswa kelas eksperimen dan kelas kontrol terdapat perbedaan dimana ketercapaian tiap indikator kelas eksperimen lebih tinggi dari pada kelas kontrol. Diketahui juga perbedaan rata-rata kemampuan berpikir kreatif siswa antara kelas eksperimen (VII.2) dan kelas kontrol (VII.1) yang menunjukkan bahwa pembelajaran matematika dengan menggunakan metode quantum learning lebih baik dibandingkan dengan menggunakan metode konvensional. 
Hasil uji normalitas data kemampuan berpikir kreatif matematis siswa disajikan dalam tabel 2 berikut :

Tabel 2. Hasil uji normalitas data kemampuan berpikir kreatif

\begin{tabular}{ccc}
\hline Kelas & Sig & Keterangan \\
\hline Eksperimen & 0,200 & Normal \\
Kontrol & 0,174 & Normal \\
\hline
\end{tabular}

Berdasarkan output Test of Normality diperoleh nilai signifikan untuk kelompok kelas eksperimen sebesar 0,200, sedangkan nilai signifikan untuk kelompok kelas kontrol sebesar 0,174. Karena nilai signifikan kelompok kelas eksperimen dan kelompok kelas kontrol > 0,05, maka dapat disimpulkan bahwa data tes siswa kelas eksperimen dan kelas kontrol berdistribusi normal.

Selanjutnya hasil perhitungan homogenitas data tes akhir kemampuan berpikir kreatif dapat dilihat pada tabel 3 berikut ini :

Tabel 3. Hasil uji homogenitas data kemampuan berpikir kreatif

\begin{tabular}{cccc}
\hline $\begin{array}{c}\text { Levene } \\
\text { statistic }\end{array}$ & df1 & df2 & Sig. \\
\hline 0,018 & 1 & 56 & 0,894 \\
\hline
\end{tabular}

Berdasarkan output Test of Homogenity diperoleh nilai signifikan untuk kelas kontrol terhadap nilai signifikan untuk kelas eksperimen sebesar 0,0894. Karena nilai signifikan kelompok kelas eksperimen dan kelas kontrol >0,05, maka dapat disimpulkan bahwa data tes kemampuan berpikir kreatif matematis siswa kelas eksperimen dan kelas kontrol dari varian yang sama (homogen).

Setelah data memenuhi syarat berdistribusi normal dan mempunyai varian yang homogen maka pengujian dapat dilanjutkan dengan perhitungan menggunakan Uji Independent Sample T-Test. Dapat dilihat pada tabel 4 hasil perhitungan data dengan uji t.

Tabel 4. Hasil uji hipotesis

\begin{tabular}{cc}
\hline \multicolumn{2}{c}{ Kemampuan berpikir kreatif matematis } \\
\hline df & Sig. (2-tailed) \\
56 & 0,001 \\
\hline
\end{tabular}

Berdasarkan hasil perhitungan uji t pada tabel 4 , tes kemampuan berpikir kreatif matematis diperoleh sig.(2-tailed) adalah 0,001<0,025. Berdasarkan kriteria pengujian maka $H_{0}$ ditolak dan $H_{a}$ diterima, sehingga disimpulkan bahwa "Ada pengaruh positif metode quantum learning terhadap kemampuan berpikir kreatif matematis siswa di SMP Negeri 5 Sekayu". 
Dari data di atas dapat dilihat bahwa ada peningkatan kemampuan berpikir kreatif matematis siswa setelah diterapkan metode quantum learning. Hal tersebut terjadi karena metode quantum learning merupakan metode yang menciptakan suasana belajar yang kondusif untuk membangun motivasi siswa dalam kegiatan belajar-mengajar sehingga mampu melatih siswa dalam menyelesaikan masalah secara mandiri melalui LKS yang diberikan.

Kemampuan berpikir kreatif matematis dalam penelitian ini didasarkan pada empat indikator, meliputi berpikir lancar, luwes, orisinal, dan merinci. Berdasarkan uraian pada deskripsi data sebelumnya maka dapat dideskripsikan bahwa kemampuan berpikir kretif matematis siswa yang diajarkan dengan menggunakan metode quantum learning lebih memberikan pengaruh yang siginifikan daripada siswa yang belajar menggunakan metode konvensional, hal ini karena dalam metode quantum learning diterapkan konsep TANDUR yang mampu membuat siswa berperan aktif dalam pembelajaran, sehingga mereka mampu menyelesaikan masalah secara mandiri.

Dalam penerapan konsep TANDUR ini guru menumbuhkan minat siswa dengan memikat siswa agar ikut serta dalam proses pembelajaran dan memuaskan proses belajar, dibangun suasana menyenangkan pada proses pembelajaran dengan didukung oleh lingkungan kelas yang baik dan hubungan guru dengan siswa, tersedia bahan-bahan untuk membangun suasana yang baik, hubungan yang baik antar guru dan murid, kegembiraan dalam pembelajaran, dan ketakjuban, pengambilan resiko, rasa saling memiliki, dan keteladanan guru. Guru membangun hubungan dengan siswa dengan adanya kepercayaan, keamanan, dan resfect mutual. Dengan adanya hal tersebut maka proses belajar mengajar akan terpaku, terfokus pada satu tujuan.

Guru memberikan pengalaman belajar untuk menumbuhkan "kebutuhan untuk mengetahui", siswa diajak untuk mengalami kegiatan belajar dengan melibatkan mereka dalam proses pembelajaran. Seluruh siswa diminta aktif berperan serta dalam kegiatan belajar. Untuk memaksimalkan proses belajar terlebih dahulu siswa harus mengetahui gaya belajar yang dimiliki. Setelah siswa mengetahui gaya belajar yang dimiliki dalam proses pembelajaran perlu melibatkan banyak gaya belajar sehingga setiap gaya belajar dapat dilayani. Semakin banyak gaya belajar yang dilibatkan maka proses pembelajaran akan semakin hidup, berarti dan melekat. Hal ini berarti semakin mudah siswa memahami materi pembelajaran.

Guru memberikan apa yang diinginkan siswa tepat pada saat minat mereka memuncak, jangan sampai mereka kecewa akibat guru bersikap acuh. Guru telah siap sedia melayani siswa yang bertanya, meminta penjelasan maupun bimbingan terhadap hal-hal yang masih samar. Guru berusaha memberikan penjelasan yang utuh mengenai aspek-aspek materi yang diajarkan. Setelah siswa diberikan permasalahan dalam LKS dan mengerjakannya perkelompok, namun setiap siswa di dalam kelompok harus mengungkapkan pendapatnya masing-masing guna mendapatkan hasil maksimal.

Guru memberikan kesempatan mereka untuk mengaitkan pengalaman dengan materi baru. Siswa diminta untuk mendemonstrasikan hasil kegiatan mereka. Kegiatan demonstrasi ini akan memberikan pengalaman yang berharga bagi siswa, dengan mengalami langsung biasanya akan terekam secara baik di ingatan siswa.

Guru berusaha merekatkan keseluruhan materi pembelajaran dengan mengulangi dan memberi penjelasan kembali secara ringkas tentang poin-poin utama 
materi pembelajaran yang telah diberikan dari awal sampai akhir. Siswa perlu memahami dan menguasai secara utuh materi pembelajaran dari awal sampai akhir.

Guru memberikan perayaan pada saat kegiatan selesai untuk menghormati usaha, ketekunan dan kesuksesan siswa. Ketika fase kegiatan belajar berakhir, tidak lupa guru memberikan perayaan, memberikan tepuk tangan sebagai penghargaan. Siswa-siswa yang berperan aktif tidak lupa untuk dihargai, agar semangat mereka makin tumbuh.

Dengan cara-cara tersebut di atas yang diterapkan oleh guru dalam pembelajaran di kelas, tentunya akan membuat siswa lebih aktif, suasana belajar lebih menyenangkan, dan mendapatkan hasil yang maksimal.

Hal ini sejalan dengan hasil penelitian dari Samad (2017), dengan mengimplementasikan model pembelajaran quantum learning, tidak hanya dapat meningkatkan hasil belajar siswa, tetapi juga membuat siswa lebih aktif dalam proses pembelajaran.

Swandewi, Gita dan Suarsana (2019) juga melakukan penelitian yang serupa yaitu melihat pengaruh model quantum learning terhadap kemampuan berpikir kreatif siswa SMA. Perbedaannya dengan penelitian ini ada pada pembelajaran yang digunakan berbasis masalah kontekstual. Meskipun terdapat perbedaan pembelajaran yang digunakan, tetapi hasil yang diperoleh dari penelitian tersebut menyimpulkan hal yang sama. Kemampuan berpikir kreatif matematika siswa yang diterapkan model pembelajaran quantum learning lebih baik dan berdampak positif dari kemampuan berpikir kreatif matematika siswa dengan model pembelajaran konvensional. Berdasarkan analisis jawaban siswa, terlihat bahwa siswa mampu menyelesaikan permasalahan dengan menggunakan berbagai macam cara.

Sama halnya dengan hasil penelitian Saputro dan Latifah (2018) bahwa pembelajaran dengan menggunakan metode quantum learning lebih efektif dibandingkan dengan menggunakan model pembelajaran konvensional. Hal ini terlihat dari siswa dapat menyelesaikan permasalahan dalam kegiatan pembelajaran dengan baik.

Berdasarkan analisis kreativitas siswa, indikator keaslian (originality) pada penelitian ini menunjukkan rata-rata yang paling tinggi dari indikator yang lain yaitu 7,21. Hal ini menunjukkan bahwa siswa memiliki kreativitas yang baik dalam menjawab soal dengan cara yang original. Hal ini serupa dengan analisis penelitian Pane (2014) bahwa indikator keaslian juga menunjukkan hasil yang baik.

Selain berpengaruh terhadap kreatifitas siswa, penerapan metode quantum learning juga memiliki dampak positif terhadap hasil belajar siswa. Sebelumnya, kurang dari 50\% siswa memperoleh nilai di atas KKM. Setelah diterapkan metode quantum learning, lebih dari 50\% siswa memperoleh hasil belajar di atas KKM. Samad (2017) juga menerapkan quantum learning dalam pembelajaran matematika. Penelitian tindakan kelas ini menyimpulkan bahwa penerapan quantum learning dalam pembelajaran dapat meningkatkan hasil belajar siswa. Sejalan juga dengan hasil penelitian Sudarman dan Vahlia (2016) yang menunjukkan hasil yang positif terhadap hasil belajar siswa.

Jadi dapat disimpulkan bahwa terdapat peningkatan kemampuan berpikir kreatif siswa setelah diterapkan metode quantum learning pada siswa kelas VII SMP Negeri 5 Sekayu. Dari hasil tersebut membuktikan bahwa metode quantum learning sebagai salah satu alternatif dalam pembelajaran matematika. 


\section{SIMPULAN DAN SARAN}

Berdasarkan analisis data maka dapat disimpulkan hasil dari penelitian ini bahwa ada pengaruh yang signifikan metode quantum learning terhadap kemampuan berpikir kreatif siswa kelas VII dalam pembelajaran matematika di SMP Negeri 5 Sekayu.

Pembelajaran dengan metode quantum learning yang menerapkan konsep TANDUR sangat bermanfaat bagi siswa, karena tercipta suasana pembelajaran yang menyenangkan. Sebaiknya metode ini diterapkan di banyak kegiatan pembelajaran matematika.

\section{DAFTAR PUSTAKA}

Anisa, Medriati, R., dan Putri, D.H. 2019. Pengaruh Model Quantum Learning terhadap Pemahaman Konsep dan Hasil Belajar Siswa Kelas X. Jurnal Kumparan Fisika, Vol. 2(3) : 201-208.

Astuti, W. 2017. Model Quantum Learning untuk Meningkatkan Hasil Belajar Pecahan. Briliant: Jurnal Riset dan Konseptual, Vol. 2(2) : 124-129.

DePorter, B. dan Hernacki, M. 2007. Quantum Learning: Membiasakan Belajar Nyaman dan Menyenangkan. Bandung: Penerbit Kaifa.

Fatahuddin, S. 2011. Penerapan Metode Quantum Learning Sebagai Upaya Peningkatan Prestasi Belajar Siswa pada Mata Diklat Penerapan Konsep Dasar Listrik dan Elektronika (PKDLE) di SMKN 2 Surakarta. Skripsi tidak diterbitkan. Yogyakarta: Program Studi Pendidikan Teknik Mekatronika Universitas Negeri Yogyakarta. [Online]. Tersedia : https://eprints.uny.ac.id /39224/1/Sholhan\%20Fatahuddin\%20-\%2006518241008.pdf. [26 april 2018].

Mardianto. 2012. Psikologi Pendidikan. Medan: Perdana Publishing.

Munandar, U. 1999. Mengembangkan Bakat dan Kreativitas Anak Sekolah. Jakarta: Rineka Cipta.

Pane, A. 2014. Peningkatan Kemampuan Berpikir Kreatif Siswa dengan Menerapkan Model Pembelajaran Quantum Learning Materi Sains. Jurnal Logaritma, Vol. 2(1) : 1-13.

Samad, I. 2017. Peningkatan Hasil Belajar Matematika Melalui Pembelajaran Quantum Learning. Jurnal Pedagogy, Vol. 2(1) : 20-30.

Saputro, T. dan Latifah, S. 2018. Efektivitas Metode Pembelajaran Quantum Learning terhadap Kemampuan Berpikir Tingkat Tinggi Peserta Didik Kelas X MA Nurul Islam Gunung Sari Ulubelu Tanggamus. Indonesian Journal of Science and Mathematics Education, Vol. 1(2) : 29-37.

Siswono, T.Y.E. 2006. Implementasi Teori tentang Tingkat Berpikir Kreatif dalam Matematika. Makalah Pada Prosiding Seminar Konferensi Nasional Matematika XIII dan Konggres Himpunan Matematika Indonesia di Jurusan Matematika FMIPA Universitas Negeri Semarang, Semarang, 24-27 Juli 2006.

Sudarman, S.W. dan Vahlia, I. 2016. Efektifitas Penggunaan Metode Pembelajaran Quantum Learning terhadap Kemampuan Pemahaman Konsep Matematis Mahasiswa. Al-Jabar: Jurnal Pendidikan Matematika, Vol. 7(2) : 275-282.

Sugiyanto. 2009. Model-model Pembelajaran Inovatif. Surakarta: Mata Padi.

Suryadi, D. dan Herman, T. 2008. Eksplorasi Matematika Pembelajaran Pemecahan Masalah. Jakarta: Karya Duta Wahana. 
Swandewi, N.L.P., Gita, I.N., dan Suarsana, I.M. 2019. Pengaruh Model Quantum Learning Berbasis Masalah Kontekstual Terhadap Kemampuan Berpikir Kreatif Siswa SMA. Jurnal Elemen, Vol. 5(1) : 31-42. 